\title{
Evaluation of polyplexes as gene transfer agents
}

\author{
Catherine L. Gebhart, Alexander V. Kabanov* \\ Department of Pharmaceutical Sciences, College of Pharmacy, 986025 Nebraska Medical Center, Omaha, NE 68198-6025, USA
}

Received 3 January 2001; accepted 4 April 2001

\begin{abstract}
Non-viral transfection systems based on the complexes of DNA and polycations ('polyplexes') were evaluated with respect to their effectiveness, toxicity and cell type dependence in a variety of in vitro models. The panel of polycations examined included branched and linear polyethyleneimines, poly[ $N$-ethyl-4-vinyl pyridinium bromide], polyamidoamine dendrimer (Superfect ${ }^{\mathrm{TM}}$ ), poly(propyleneimine) dendrimer (Astramol ${ }^{\mathrm{TM}}$ ) and a conjugate of Pluronic ${ }^{\circledR}$ P123 and polyethyleneimine (P123-g-PEI(2K)), having a graft-block copolymer architecture. Using a panel of cell lines the linear polyethyleneimine ExGen ${ }^{\mathrm{TM}} 500$, Superfect ${ }^{\mathrm{TM}}$, branched polyethyleneimine $25 \mathrm{kDa}$, and P123-g-PEI(2K) were determined as systems displaying highest transfection activity while exhibiting relatively low cytotoxicity. These systems had activity higher than or comparable to lipid transfection reagents (Lipofectin ${ }^{\circledR}$, LipofectAMINE $^{\text {TM }}$, CeLLFECTIN $^{\circledR}$ and DMRIE-C) but did not reveal serum dependence and were less toxic than the lipids. Overall, this study demonstrates good potential of structurally diverse polyplex systems as transfection reagents with relatively low cytotoxicity. (C) 2001 Elsevier Science B.V. All rights reserved.
\end{abstract}

Keywords: Polyplex; Lipoplex; Transgene expression; Polycation; DNA

\section{Introduction}

The field of non-viral gene therapy has recently gained increased interest [1]. It is widely believed that non-viral gene therapy can overcome some problems inherent to current viral based therapies, including immune and toxic reactions as well as the potential for viral recombination [2]. One major approach in non-viral gene therapy is based on 'polyplexes', complexes formed by mixing DNA with synthetic polycations $[3,4]$. The polyplexes form spontaneously as a result of electrostatic inter-

\footnotetext{
*Corresponding author. Tel.: +1-402-559-9915; fax: +1-402559-9543.

E-mail address: akabanov@mail.unmc.edu (A.V. Kabanov).
}

actions between the positively charged groups of the polycation and the negatively charged phosphate groups of the DNA. A variety of polycation molecules have been proposed for polyplex formation [4]. These molecules differ in the chemical composition and the number of the repeating units, as well as in the architecture of the polymer backbone, which may be linear, randomly branched, dendrimeric, block-or graft copolymer. As a result, a wide range of different polyplexes can be easily synthesized and evaluated in order to determine the most efficient systems. The studies in this field are focused on increasing efficiency of transgene expression and improving bioavailability of the polyplex, while decreasing its toxicity (reviewed in Ref. [5]).

Information relating biological performance to the 
chemical structure of polyplex systems is critically needed to allow for the development of novel gene delivery formulations [6]. However, relatively little work compares various polyplex systems with each other. Furthermore, even less literature is available comparing polyplexes with another major class of non-viral gene delivery systems based on the complexes of DNA with cationic lipids ('lipoplexes'). To address these problems we have evaluated several representative transfection systems with respect to their effectiveness, toxicity and cell type dependence in a variety of in vitro models. Polyethyleneimine (PEI) transfection systems were represented by three samples differing in the molecular mass and degree of branching including linear PEI (22K) $\left(\mathrm{ExGen}^{\mathrm{TM}}\right.$ $500)$, linear PEI $(50 \mathrm{~K})$, and branched PEI (25K) [7-9]. Poly[ $N$-ethyl-4-vinyl pyridinium bromide] $\left(\mathrm{PEVP}_{362}\right)$, one of the early polycations used for preparation of polyplexes, was examined as an example of a linear molecule containing quaternized nitrogen atoms [10]. Dendrimer architecture was represented by the degraded polyamidoamine dendrimer, Superfect ${ }^{\mathrm{TM}}$ [11] and the poly(propyleneimine) dendrimer, Astramol ${ }^{\mathrm{TM}}$ Am-64 (Am-64) [12] [13]. Finally, the copolymer obtained by conjugation of Pluronic ${ }^{\circledR}$ P123 and PEI (2K), P123-g-PEI(2K), served as an example of a graftblock copolymer architecture [14]. Thus we have used all major representative polyplex classes reported in the literature [3]. These systems were also compared with some frequently used lipid transfection reagents including Lipofectin $^{\circledR}$, LipofectAMINE $^{\mathrm{TM}}$, CeLLFECTIN $^{\circledR}$ and DMRIE-C. Since successful transfection may strongly vary depending on the cell type, the experimental in vitro models used cells from a variety of tissues including breast, kidney, and colon, which are likely targets for gene therapy. The results of the studies illustrate the extent to which the transfection activity and toxicity in these systems can be optimized by varying structure and composition of the polyplex.

\section{Materials and methods}

\subsection{Chemicals}

PEI (50K) was purchased from Monomer-Polymer
Dajac Laboratories, PEI (25K) and Am-64 were obtained from Sigma-Aldrich (St. Louis, MO). PEI (25K), PEI (50K) and Am-64 were dialyzed twice against $\mathrm{ddH}_{2} \mathrm{O}$ using Membra-Cel MD-25-03.5 (Applied Technologies Group, Chicago, IL). PEVP ${ }_{362}$ (poly[ $N$-ethyl-4-vinyl pyridinium bromide]) was synthesized as described previously [15]. All of the above polycations were resuspended in $\mathrm{ddH}_{2} \mathrm{O}$ at a concentration of $10 \mu \mathrm{mol} \mathrm{NT} / \mathrm{ml}$. ExGen ${ }^{\mathrm{TM}} 500$ (Euromedex, Souffleweyersheim) and Superfect ${ }^{\mathrm{Tm}}$ (Qiagen, Valencia, CA) solutions were used as provided by the manufacturers. Nonionic block copolymer Pluronic ${ }^{\circledR}$ P123 was kindly provided by BASF (Parispany, NJ). This copolymer has a triblock structure, poly(ethylene oxide)-block-poly(propylene oxide)-block-poly(ethylene oxide), and has an average of 70 propylene oxide and 40 ethylene oxide repeating units: $\mathrm{EO}_{20}-\mathrm{PO}_{70}-\mathrm{EO}_{20}$. $\mathrm{P} 123$-g-PEI(2K) was synthesized by grafting P123 to the amino groups of PEI, as described previously [14]. Finally, Transfection Reagent Sample Pack, containing Lipofectin $^{\circledR}$, LipofectAMINE ${ }^{\text {TM }}$, CeLLFECTIN $^{\circledR}$ and DMRIE-C, was purchased from Life Technologies (Gaithersburg, MD) and were used as provided by the manufacturers.

\subsection{Plasmid DNA}

The luciferase encoding plasmid pCMV-luc (7.2 $\mathrm{kb}$ ), under the control of the CMV promoter, used for this work was provided by Dr. Albert Descoteaux (Armand Frappier Institute, Montreal, PQ, Canada). The plasmid was expanded in DH5 $\alpha$ E. coli and was isolated using Qiagen endotoxin-free plasmid Gigaprep kits according to the supplier's protocol. The quantity and quality of the purified plasmid DNA was assessed by spectrophotometric analysis at 260 and $280 \mathrm{~nm}$ as well as by electrophoresis in $0.8 \%$ agarose gel. Purified plasmid DNA was resuspended in sterile $\mathrm{ddH}_{2} \mathrm{O}$ and frozen in aliquots at a concentration of $0.1 \mathrm{mg} / \mathrm{ml}$.

\subsection{Cell lines and cell culture}

R.T. Borchadt (University of Kansas, Lawrence, KS), kindly provided the human colorectal adenocarcinoma, Caco-2 (ATCC HTB-37). Dr. D.W. Miller (University of Nebraska Medical Center, Omaha, 
$\mathrm{NE}$ ), provided the human epithelial line KB (ATCC CCL-17), as well as its drug-resistant subline, KBv. The monkey kidney fibroblast line Cos-7, the murine myoblast line C2C12 (ATCC CRL1772), the human breast adenocarcinoma line MCF7 (ATCC HTB-22) and its drug-resistant subline, MCF7 ADR were provided by Dr. V. Alakhov (Supratek Pharma, Laval, Canada). The porcine kidney epithelial cell line, LLC-PK1, and its drug-resistant subline, LLCMDR1, were provided by Dr. W. Elmquist (University of Nebraska Medical Center, Omaha, NE). Dr. James Talmadge (University of Nebraska Medical Center, Omaha, NE) provided CT26, a non-immunogenic murine colon carcinoma line derived from $\mathrm{BALB} / \mathrm{c}$ mice.

The cell lines Caco-2, C2C12, CT26, Cos-7, KB and $\mathrm{KBv}$ were grown in Dulbecco's modified Eagle medium (DMEM) supplemented with $10 \%$ heatinactivated fetal bovine serum (FBS), $10 \mathrm{mM}$ Hepes and $100 \mathrm{U} / \mathrm{ml}$ penicillin/100 $\mu \mathrm{g} / \mathrm{ml}$ streptomycin. $\mathrm{KBv}$ was cultured in the presence of $1 \mu \mathrm{g} / \mathrm{ml}$ vinblastine (Faulding Pharmaceutical, Elizabeth, $\mathrm{NJ}$ ). MCF7 and its resistant subline, MCF7 ADR, were grown in the same media mentioned above, except the Hepes was increased to $1 \%$ and MCF7 ADR was cultured in the presence of $10 \mathrm{ng} / \mathrm{ml}$ doxorubicin (Gensia Laboratories, Irvine, CA). LLC-PK1 and LLC-MDR were grown in Medium 199 supplemented with $10 \%$ FBS, $10 \mathrm{mM}$ Hepes and 100 $\mathrm{U} / \mathrm{ml}$ penicillin/100 $\mu \mathrm{g} / \mathrm{ml}$ streptomycin. LLCMDR was cultured in the presence of $640 \mathrm{nmol} / \mathrm{ml}$ vincristine (SP Pharmaceuticals, Albuquerque, NM). All tissue culture reagents were obtained from Gibco Life Technologies (Grand Island, NY). In subsequent sections of this paper, complete medium refers to the appropriate medium for a given cell type, supplemented with Hepes, penicillin/streptomycin and FBS, as outlined above.

\subsection{Formation of complexes}

The precise mixing order of the transfecting solutions is a critical parameter in the outcome of the transfections and therefore the ensuing protocol was followed exactly for all transfections. To a $1.5 \mathrm{ml}$ eppendorf tube, the following were added (1) $45 \mu \mathrm{l}$ of DNA $(0.1 \mathrm{mg} / \mathrm{ml}),(2) 150 \mu \mathrm{l}$ of DMEM with $1 \%$ Hepes and lastly (3) $52 \mu$ l of polycation (diluted in
$\mathrm{ddH}_{2} \mathrm{O}$ to obtain appropriate $\mathrm{N} / \mathrm{P}$ ratio). The tube was capped immediately following addition of polycation and vortexed for $30 \mathrm{~s}$. The mixture was then allowed to incubate at room temperature for $5 \mathrm{~min}$ and then $1253 \mu \mathrm{l}$ of complete medium were added. In the case of P123:P123-g-PEI(2K), prior to addition of P123-g-PEI(2K), $9 \mu \mathrm{l}$ of $50 \mathrm{mg} / \mathrm{ml}$ Pluronic P123 were added to the DNA/DMEM mixture.

\subsection{In vitro transfection}

Transfection protocols varied throughout these studies as indicated for individual experiments. Cells were always seeded at the same density at $7 \times 10^{4}$ cells per well in 12 -well plates or $3.5 \times 10^{4}$ cells per well in 24-well plates. Cells were grown to from 40 to $95 \%$ confluency as determined visually. Immediately prior to transfection, cells were washed once with PBS, and then the transfection mixture was added to each well $(1.5 \mu \mathrm{g}$ DNA per $500 \mu \mathrm{l}$ per well in 12-well plates or $0.75 \mu \mathrm{g}$ DNA per $250 \mu \mathrm{l}$ per well in 24-well plates). Cells were exposed to transfection agents for 2,4 or $5 \mathrm{~h}$ as indicated for individual experiments, at $37^{\circ} \mathrm{C}\left(5 \% \mathrm{CO}_{2}\right)$. After that cells were rinsed once with PBS, allowed to rest overnight in $1 \mathrm{ml}$ (12-well plates) or $0.5 \mathrm{ml}$ (24-well plates) of complete medium and then harvested. Luciferase assay was performed according to Promega recommendation. Briefly, cells were lysed in 150 $\mu l$ of $1 \times \mathrm{CCLR}$ at $37^{\circ} \mathrm{C}$, with shaking for $30 \mathrm{~min}$ and then centrifuged at $13000 \times g$ for 2 min. Supernatants were collected and analyzed for luciferase activity. In a typical experiment $10 \mu \mathrm{l}$ of supernatant was added to luminometric tubes and $100 \mu \mathrm{l}$ of luciferase substrate was autoinjected by a Turner Designs: TD-20/20 Luminometer. Following a 5-s delay after injection, light emission was measured for a period of $20 \mathrm{~s}$ for samples and for a luciferase standard calibration curve. Results were then converted to $\mathrm{ng}$ luciferase per $\mathrm{ml}$ based on the calibration curve. Cellular protein assays were performed with the BCA Protein Assay (Pierce, Rockford, IL) to allow for the final conversion of the data to ng luciferase per $\mathrm{mg}$ protein. The data was reported as mean \pm standard deviation for triplicate samples. Unless otherwise indicated, all data in this paper contain only those transfections in which the reduction in cellular protein, compared to control 
wells (exposed to the same amount of the naked DNA), was less than $20 \%$, to avoid the complication of toxicity in analysis of the data.

\subsection{MTT assays}

Cos-7 cells were seeded $24 \mathrm{~h}$ prior to treatment in 96-well plates at 2500 cells per well, all other cell lines were seeded at 5000 cells per well. Cells were treated with the same conditions used for luciferase assays, with a volume of $46 \mu \mathrm{l}$ of the transfection mixture added to each well during treatment to correspond exactly to the surface area to volume ratios used with 12-well plate transfections. Cells were treated with the appropriate conditions for either 2 or $4 \mathrm{~h}$, washed once with PBS, and cultured in $200 \mu \mathrm{l}$ of complete media (appropriate for each cell line, in the absence of drug in the case of resistant cell lines) for an additional $72 \mathrm{~h}$. Culture media was replaced with $100 \mu \mathrm{l}$ of fresh media and then $25 \mu \mathrm{l}$ of MTT (3-(4,5-dimethylthiazol-2-yl)2,5diphenyltetrazolium bromide) reagent $(5 \mu \mathrm{g} / \mathrm{ml}$ in PBS) was added to each well. Following a 2-h incubation at $37^{\circ} \mathrm{C}, 100 \mu \mathrm{l}$ of solvent (50\% dimethyl formamide, $20 \%$ sodium dodecyl sulfate, $\mathrm{pH} 4.7$ ) were added to each well. Plates were incubated at $37^{\circ} \mathrm{C}$ overnight and then absorbance at $570 \mathrm{~nm}$ was read in a BT2000 Microkinetics reader.

\subsection{Agarose gel electrophoresis}

Complexes were prepared by combining $6 \mu \mathrm{l}$ of DNA $(0.1 \mathrm{mg} / \mathrm{ml})$ with the appropriate amount of $\mathrm{ddH}_{2} \mathrm{O}$ and polycation to obtain the desired N/P ratio value in a total volume of $26 \mu \mathrm{l}$. The resulting complexes were placed at room temperature for 30 min prior to electrophoresis. Four $\mu$ l of loading dye were added to each sample and $15 \mu$ of each sample were loaded per well. DNA complexes were analyzed by electrophoresis in a $0.8 \%$ agarose gel with $0.04 \mathrm{M}$ Tris-acetate buffer, $\mathrm{pH} 7.4$, containing 1 mM EDTA, at $45 \mathrm{~V}$ for $2 \mathrm{~h}$. DNA was visualized by UV illumination following staining of gels with ethidium bromide $(0.5 \mu \mathrm{g} / \mathrm{ml})$ for $60 \mathrm{~min}$ at room temperature.

\subsection{Particle size measurements}

The effective hydrodynamic diameter was deter- mined by photon correlation spectroscopy technique at $22^{\circ} \mathrm{C}$ and an angle of $90^{\circ}$ using a 'ZetaPlus' Zeta Potential Analyzer (Brookhaven Instrument) with a $15-\mathrm{mV}$ solid state laser operated at a wavelength of $635 \mathrm{~nm}$ equipped with the Multi Angle Option. The effective diameter was calculated by the software supplied with the instrument as a diameter of equivalent hydrodynamic spheres from the $z$-average diffusion coefficients using the Stokes's-Einstein equation. The resulting value is a hydrodynamic characteristic averaged for the entire population of the particles present in the system. The polydispersity, a parameter characterizing the range of the particle size distribution is obtained using the software supplied with the Brookhaven instrument.

\subsection{Statistical analysis}

The statistical significance of the intra-experimental variations between different treatment groups was evaluated with a two-tailed heteroscedastic $t$-tests using Microsoft Excel 97 SR-1 program. A minimum $P$ value of 0.05 was used as the significance level in these tests. The inter-experimental variations during evaluation of a panel of polyplexes in different cell were analyzed using a Kruskal-Wallis ranking test.

\section{Results}

\subsection{Formation of complexes}

In this paper we use $\mathrm{N} / \mathrm{P}$ ratio, i.e., the ratio of concentrations of total nitrogen atoms $(\mathrm{N})$ of the polycation to the phosphate groups $(\mathrm{P})$ of DNA, as the characteristic of the composition of the transfection system. Complexes of plasmid DNA and polycations were prepared at various $\mathrm{N} / \mathrm{P}$ ratios by simple mixing in the appropriate media, as indicated for individual experiments. The commercially available transfection reagents, Superfect ${ }^{\mathrm{TM}}$ and ExGen ${ }^{\mathrm{TM}}$ 500 , were mixed with the DNA at the ratios recommended by the manufacturer for transfection experiments, and as indicated for electrophoresis experiments described below. The polyplex based on P123-g-PEI(2K) also contained free Pluronic ${ }^{\circledR}$ P123, which was added to prevent aggregation of the 
complexes and enhance their transfection activity as reported previously [14].

\subsection{Determination of optimal transfection N/P ratio}

Complexes formed between plasmid DNA and cationic copolymers were assessed for their in vitro transfection activity utilizing the transient expression of a luciferase plasmid, pCMV-Luc, in Cos-7 cells. To determine the optimal transfection ratio, cells were transfected with polyplexes at various $\mathrm{N} / \mathrm{P}$ ratios (or $\mu \mathrm{g}$ polycation per $\mathrm{nM}$ DNA phosphate for Superfect ${ }^{\mathrm{TM}}$ ). Cells were harvested $24 \mathrm{~h}$ following transfection and the resulting levels of luciferase, as well as cellular protein, were quantified. All transfection data was expressed as ng luciferase per $\mathrm{mg}$ cellular protein. Cellular toxicity was assessed in these experiments both visually and by monitoring cellular protein levels. (Our study suggested that there is good correlation between cytotoxicity as assessed by decrease in the cell protein levels and results obtained using the MTT assay, data not presented.)

For all polyplexes, it was found that the efficiency of transfection was dependent on the N/P ratio. The cellular toxicity was also dependent on the N/P ratio. As a result all polyplexes revealed one of two types of behavior. In one case illustrated in Fig. 1A using PEI $(25 \mathrm{~K})$ as an example there was a sharp peak in luciferase expression upon variation of the $\mathrm{N} / \mathrm{P}$ ratio. No obvious cytotoxicity was observed in this case. In another case illustrated in Fig. 1B using $\mathrm{PEVP}_{362}$ as an example luciferase expression continued to increase with increasing N/P ratio to the point where the toxicity became very apparent. In this case the tolerable cytotoxicity was set as no more than a $20 \%$ decrease in the cell protein levels compared to control (cells exposed to the same amount of the naked DNA). Based upon these observations the optimal transfection N/P ratios were determined for all polycations, which corresponded to either the point of the peak of luciferase expression or the point of maximal luciferase expression with the cytotoxicity below the above cut-off point. Summary results listing optimal N/P ratios for all polyplexes are presented in Table 1. It is noteworthy that for all polyplexes examined the optimum occurred under conditions of excess of polycation

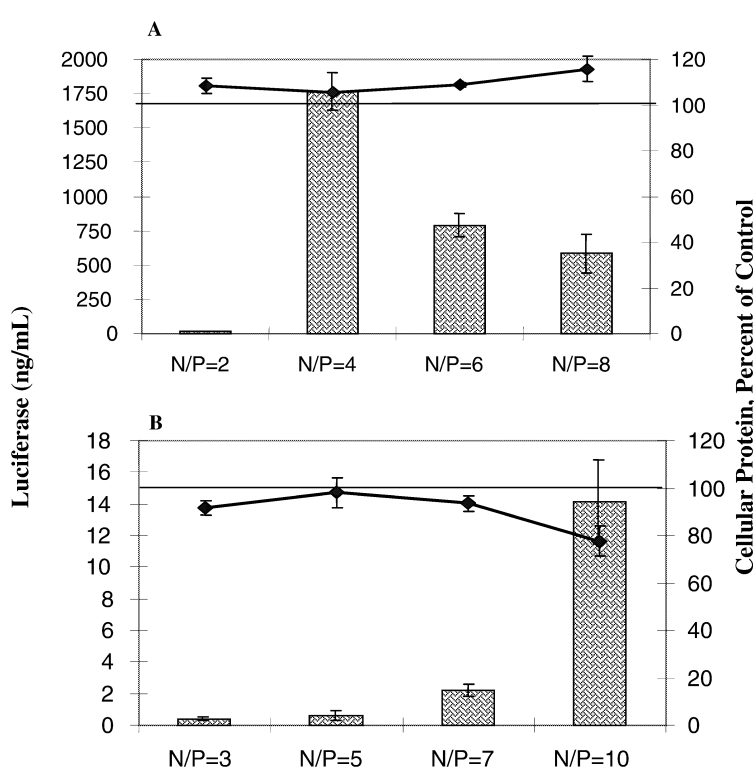

Fig. 1. Determination of optimal transfection N/P ratio in Cos-7 cells. Representative results for two polyplex systems are shown: (A) PEI(25K) and (B) PEVP ${ }_{362}$. Cos-7 cells were transfected with pCMV-Luc plasmid incorporated into polyplexes at various $\mathrm{N} / \mathrm{P}$ ratios, as indicated in the figure. Bars present the luciferase expression ( $\mathrm{ng} / \mathrm{ml}$, left axis). Points present the cellular protein (percent of cellular protein in treated wells compared to cellular protein in control wells, right axis). Transfections were performed using $85 \%$ confluent cells, which were exposed to the polyplexes at a DNA dose of $1.5 \mu \mathrm{g} /$ well $(3 \mu \mathrm{g} / \mathrm{ml})$ in 12-well plates in the presence of serum for $4 \mathrm{~h}$. The data are presented as means \pm S.D. $(n=3)$.

charged groups relative to DNA charges. The only exception was Am-64, which exhibited high toxicity at $\mathrm{N} / \mathrm{P}$ ratios exceeding $\mathrm{N} / \mathrm{P}=4$. Table 1 also presents the sizes of the polyplexes and points of the DNA neutralization with the polycation, which will be discussed later.

\subsection{Transfection of Cos- 7 cells using various polyplexes}

The relative ability of each polyplex to transfect mammalian cells was examined using a Cos-7 cell model. The following polyplexes were tested: Superfect $^{\text {TM }}$, ExGen ${ }^{\text {TM }}$ 500, P123-g-PEI(2K), PEI (50K), PEI (25K), PEVP 362 and Am-64. Cells were transfected for $2 \mathrm{~h}$ with polyplexes, at the optimal transfection ratio as determined above for Cos-7 cells. For each polyplex the transfection experiment was performed in triplicate wells and it was repeated 
Table 1

Transfection, size and neutralization characteristics of the polyplexes

\begin{tabular}{llll}
\hline Polycation & {$[\mathrm{N} / \mathrm{P}]_{\mathrm{o}}{ }^{\mathrm{a}}$} & $D_{\text {eff }}{ }^{\text {at }[\mathrm{N} / \mathrm{P}]_{\mathrm{o}}{ }^{\mathrm{b}}}$ & {$[\mathrm{N} / \mathrm{P}]_{\mathrm{e}}{ }^{\mathrm{c}}$} \\
\hline ExGen $^{\text {TM }} 500$ & 9 & 119 & 1.5 \\
Superfect $^{\mathrm{T} M}$ & $5 \mu \mathrm{g} / \mathrm{nmol}$ & 122 & $0.5 \mu \mathrm{g} / \mathrm{nmol}$ \\
Branched PEI (25K) & 4 & 238 & 2.5 \\
Linear PEI (50K) & 6 & 371 & 2.0 \\
P123-g-PEI (2K) & 10 & 149 & 2.0 \\
AM-64 & 4 & 265 & 4.0 \\
PEVP $_{362}$ & 10 & 420 & 1.0 \\
\hline
\end{tabular}

${ }^{\mathrm{a}}[\mathrm{N} / \mathrm{P}]_{\mathrm{o}}$ refers to the molar ratio of the polycation nitrogen groups to the DNA phosphate groups, which was determined to be optimal for transfection in Cos-7 cells as discussed in the Section 3. The nitrogen content was unavailable for Superfect ${ }^{\mathrm{TM}}$, for which net weight of polycation per nmol of the DNA phosphate groups is presented.

${ }^{\mathrm{b}} D_{\text {eff }}$ at $[\mathrm{N} / \mathrm{P}]_{\mathrm{o}}$ refers to the effective diameter $(\mathrm{nm})$ of the complexes observed by particle size analysis when complexes are formed at $[\mathrm{N} / \mathrm{P}]_{\mathrm{o}}$ in complete media (containing serum).

${ }^{c}[\mathrm{~N} / \mathrm{P}]_{\mathrm{e}}$ refers to the ratio of total nitrogen to phosphate corresponding to the complete neutralization of DNA as determined by electrophoresis.

at least two times as indicated in the legend for Fig. 2. There was little variability within experiments (S.E.M. values less than $5 \%, n=3$ ) but there was significant inter-experimental variability for repeated transfections with the same polyplex. Therefore, the results are presented in Fig. 2 as the ranges between the lowest value and the highest value that were obtained with each polyplex over a series of experiments. Based upon this data, ExGen ${ }^{\mathrm{TM}} 500$ and Superfect ${ }^{\text {TM }}$ were generally the most active polymers

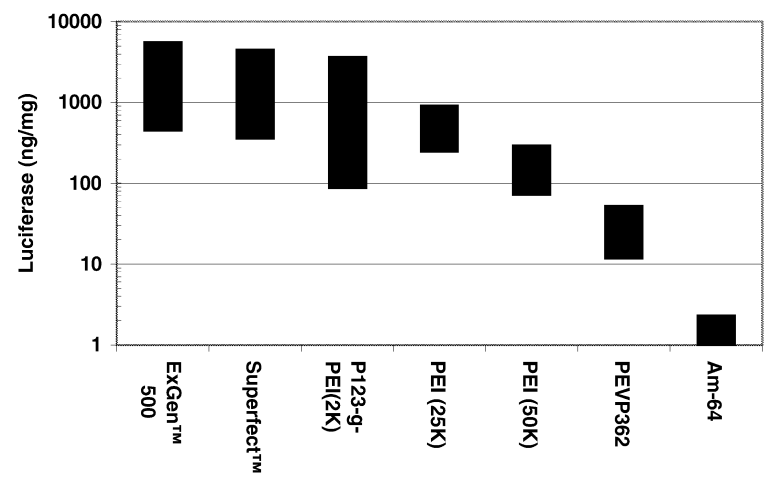

Fig. 2. Relative transfection activity of various polyplexes in Cos-7 cells. Data represent the range from the lowest to the highest values of luciferase expression ( $\mathrm{ng} / \mathrm{mg}$ ) obtained following transfection with a given polyplex over a series of experiments. The number of repeated experiments for each polyplex are as follows: $\operatorname{ExGen}^{\mathrm{TM}}$ 500, 9; Superfect, 11; P123-g-PEI, 8; PEI(25K), 6; PEI(50K), 5; PEVP ${ }_{362}, 2$; and AM-64, 4. Transfections were performed using $85 \%$ confluent cells, which were exposed to the polyplexes at a DNA dose of $1.5 \mu \mathrm{g} /$ well (3 $\mu \mathrm{g} / \mathrm{ml})$ in 12-well plates in the presence of serum for $4 \mathrm{~h}$. in the majority of cell lines, PEI (25K) and P123-gPEI were of intermediate activity, while PEI (50K), Am-64 and PEVP $_{362}$ were the least active. The transgene expressions using naked DNA controls were extremely low and rarely detectable compared to the transgene expressions achieved using polyplexes.

\subsection{Cell type dependence of the transfection using polyplexes}

Luciferase expression was evaluated following transfection at the predetermined optimal N/P ratios (see Table 1) with various polyplexes in several cell lines in order to assess cell type dependence of the transfection process using polyplexes. The cell panel used in these experiments included a variety of mammalian cells (Cos-7, LLC-PK1, LLC-MDR1, MCF-7, MCF-7/ADR, KB，KBv，CT26， C2C12 myoblast, Caco-2). Fig. 3 presents data for ExGen ${ }^{\text {TM }}$ 500-containing polyplex, which, based on these studies, was among the most active transfection agents in practically all cell lines. Like in the previous figure these data show the range between the lowest and the highest values obtained in repeated experiments. Three cell lines (Cos-7, LLCPK1 and LLC-MDR1) demonstrated the ability to produce far more luciferase than any other cell line examined (at levels above $100 \mathrm{ng} / \mathrm{mg}$ ). The remaining seven lines, while demonstrating detectable 


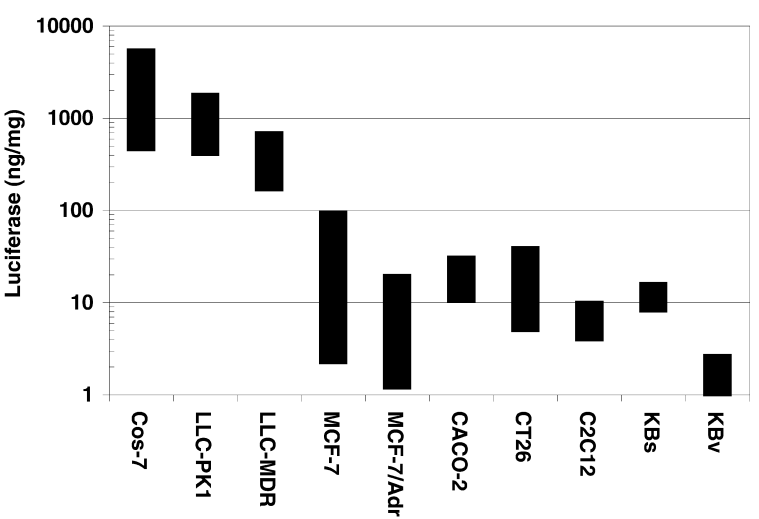

Fig. 3. Relative 'transfectability' of various cell lines using the ExGen $^{\mathrm{TM}}$ 500-based polyplex. Data represents the range from low to high values obtained for each cell line for a minimum of three separate transfection experiments. The number of experiments represented for each cell line are as follows: Cos-7, 9; LLC-PK1, 4; LLC-MDR, 4; MCF-7, 4; MCF-7/Adr, 4; CACO-2, 3; CT26, 3; $\mathrm{C} 2 \mathrm{C} 12,3$; KBs, 3; and $\mathrm{KBv}, 3$. Transfections were performed using $95 \%$ confluent cells, which were exposed to the polyplexes at a DNA dose of $1.5 \mu \mathrm{g} /$ well $(3 \mu \mathrm{g} / \mathrm{ml})$ in 12-well plates in the presence of serum for $2 \mathrm{~h}$.

levels of transgene expression, produced less than $100 \mathrm{ng} / \mathrm{mg}$ of luciferase in this system.

Data for the four most active polycations, ExGen $^{\text {TM }}$ 500, Superfect ${ }^{\text {TM }}$, P123-g-PEI(2K) and PEI $25 \mathrm{~K}$, were analyzed in an attempt to rank effectiveness of those transfecting agents in the cell panel described above. The ranking was done using the Kruskal-Wallis test [16]. As is seen in Table 2, by this method of ranking, ExGen ${ }^{\text {TM }} 500$ appears to be the best transfecting reagent choice for a large number of cell lines (8/10). It was closely followed by Superfect $^{\mathrm{TM}}$, while PEI (25K) and P123-g$\operatorname{PEI}(2 \mathrm{~K})$ were somewhat less effective in the studied panel.

\subsection{Cell confluency and exposure time}

To evaluate the effects of the cell confluency and the effects of time of exposure of the cells to the transfection complexes on the efficiency of transgene expression using polyplexes this study examined the two most effective polycation systems ExGen ${ }^{\top \mathrm{M}} 500$ and Superfect ${ }^{\mathrm{TM}}$. For each of these systems Cos-7 cells were grown to 40,70 and $90 \%$ confluency and then exposed to the transfection complexes for either 2 or $4 \mathrm{~h}$. Fig. 4A presents the results of the transgene expression assay, while Fig. 4B presents the results of the cytotoxicity evaluation performed for each transfection using MTT assay.

With Exgen 500 the transgene expression was increasing when the cell density was increased. Furthermore, there was statistically no difference in the transgene expression between $2 \mathrm{~h}$ and $4 \mathrm{~h}$ exposure of the cells to the ExGen ${ }^{\mathrm{TM}}$ 500-based polyplex at the lower confluencies of 40 and $70 \%$. At

Table 2

Ranking ${ }^{\mathrm{a}}$ of effectiveness of active polyplexes in various cell lines

\begin{tabular}{|c|c|c|c|c|}
\hline Cell line & $\operatorname{ExGen}^{\mathrm{TM}} 500$ & Superfect ${ }^{\mathrm{TM}}$ & $\begin{array}{l}\text { PEI } \\
(25 \mathrm{~K})\end{array}$ & $\begin{array}{l}\text { P123-g-PEI } \\
(2 \mathrm{~K})\end{array}$ \\
\hline Cos-7 & II & I & III & IV \\
\hline LLC-PK1 & I & III & IV & II \\
\hline LLC-MDR & I & II & IV & III \\
\hline MCF-7 & III & II & I & IV \\
\hline MCF-7/Adr & I & III & II & IV \\
\hline CACO-2 & I & II & IV & III \\
\hline CT26 & I & III & II & IV \\
\hline $\mathrm{C} 2 \mathrm{C} 12$ & I & IV & III & II \\
\hline KBs & I & II & II & IV \\
\hline $\mathrm{KBv}$ & I & II & III & $\mathrm{n} / \mathrm{d}^{\mathrm{b}}$ \\
\hline
\end{tabular}

${ }^{a}$ A panel of polyplexes were tested with each cell line in at least three separate experiments. The results were analyzed using Kruskal-Wallis ranking test. This analysis shows, for each cell line, which polyplex more frequently performs better than others in a series of repeated evaluations of the polyplex panel. As a result, even if in one individual experiment a polyplex shows higher transfection efficacy than the other members of the panel (such as ExGen ${ }^{\mathrm{TM}} 500$ in Cos-7 cells, see Fig. 3), it is not ranked the best for a given cell line if it is not the most frequent best performer in the series of repeated evaluations.

${ }^{\mathrm{b}} \mathrm{n} / \mathrm{d}$ indicates that the given condition was not tested. 

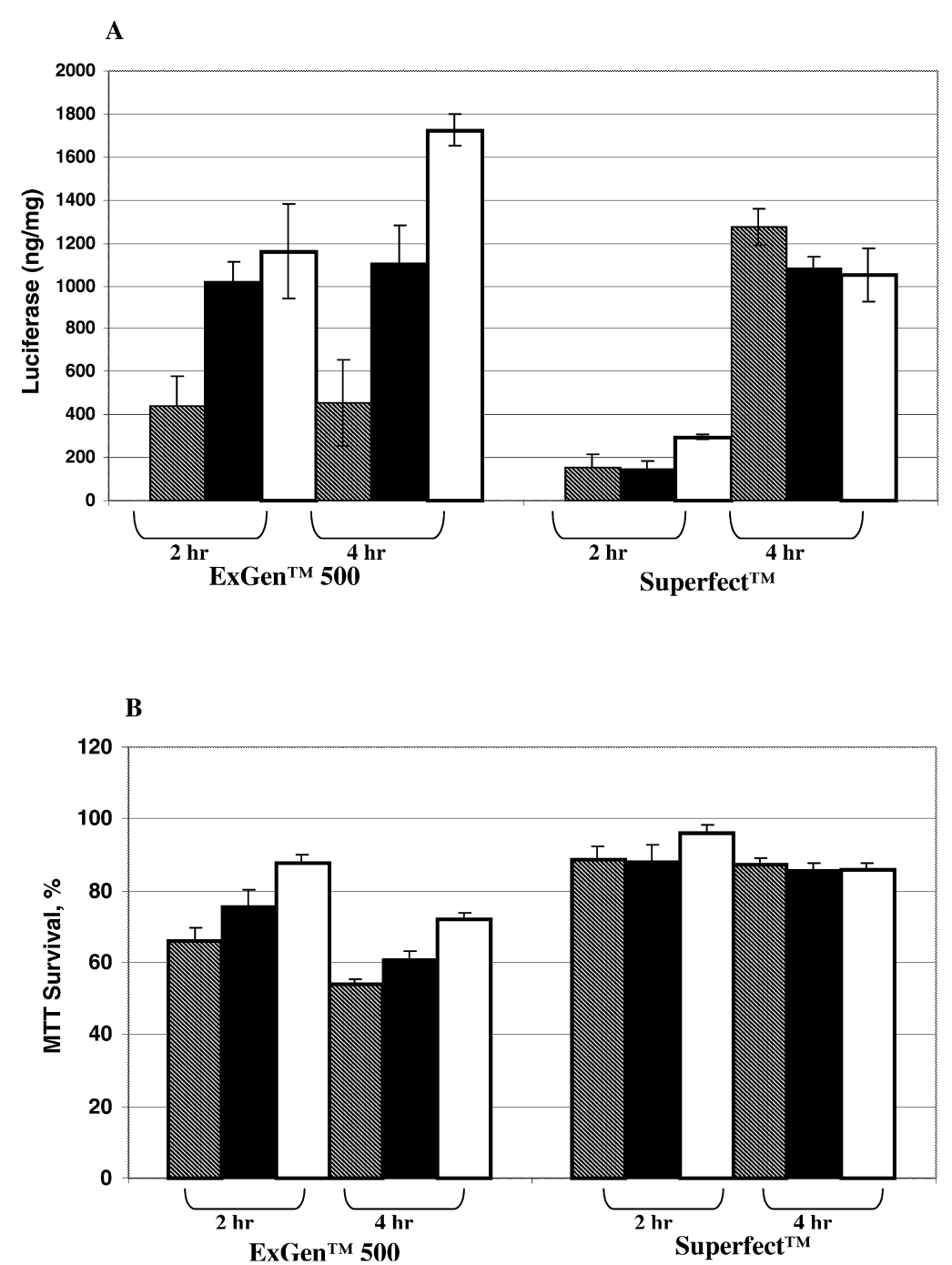

Fig. 4. Evaluation of the effect of confluency and transfection time on (A) the transgene expression and (B) cytotoxicity of ExGen ${ }^{\mathrm{TM}} 500$ and Superfect ${ }^{\mathrm{TM}}$. Cos-7 cells were grown to various confluencies: $40 \%$ (striped bars), $70 \%$ (solid bars) and $90 \%$ (white bars). Cells were then transfected using polyplexes at a DNA dose of $0.75 \mu \mathrm{g} /$ well $(3 \mu \mathrm{g} / \mathrm{ml})$ in 24-well plates in the presence of serum for either 2 or $4 \mathrm{~h}$. Percent of cell survival was determined using a MTT assay. The data are presented as means \pm S.D. $(n=3)$.

$90 \%$ confluency the transgene expression increased by ca. 1.5 times when the exposure of the cells to this polyplex was increased from 2 and $4 \mathrm{~h}$. In the cytotoxicity assay increase in the time of exposure of the cells to this polyplex resulted in $10-20 \%$ decrease in the cell survival for each of the confluences examined. At each exposure time increase in the confluency resulted in decrease in toxicity.
In contrast, Superfect ${ }^{\mathrm{TM}}$ was much better tolerated allowing longer exposure times of the cells to the complexes at any confluency examined. Furthermore, in the transgene expression assay the duration of exposure of the cells to the Superfect ${ }^{\mathrm{TM}}$-based polyplex was critical. A 2-h exposure was clearly insufficient to obtain efficient transfection at any confluence compared to the results of the 4-h expo- 
sure. At $4 \mathrm{~h}$, high transfection levels, comparable to those observed with ExGen ${ }^{\mathrm{TM}}$ 500, were achieved with Superfect ${ }^{\mathrm{TM}}$.

\subsection{Comparison of polyplexes versus lipoplexes}

Fig. 5A presents the data on the transfection activities of LipofectAMINE ${ }^{\mathrm{TM}}$-based lipoplex and ExGen $^{\text {TM }}$ 500-based polyplex. These transfection systems were compared using a Cos-7 cell model transfected for 2 and $4 \mathrm{~h}$ at various DNA doses. The cell confluency was $95 \%$ to minimize the toxicity effects. Indeed for both complexes studied at the highest DNA dose used ( $2 \mu \mathrm{g} /$ well) the cell protein levels were not less than $70 \%$ of controls (exposed to the same amount of the naked DNA). As is seen in the figure both at 2 and $4 \mathrm{~h}$ the polyplex produced high luciferase expression at substantially lower concentrations of DNA than the lipoplex. Fig. 5B presents the data for the relative transfection $(4 \mathrm{~h})$ normalized for the DNA dose. It shows that at the conditions examined the polyplex produced substantially more transgene expression per DNA copy than the lipoplex.

A

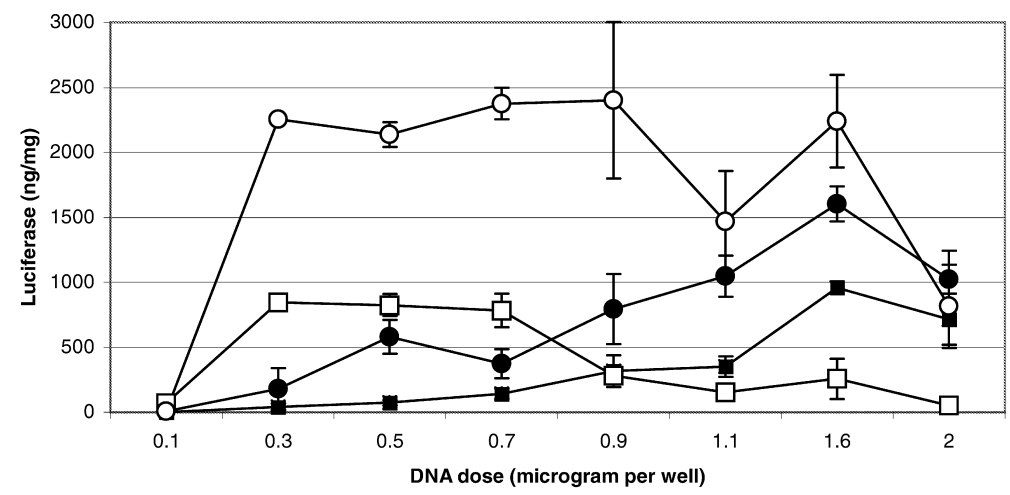

B

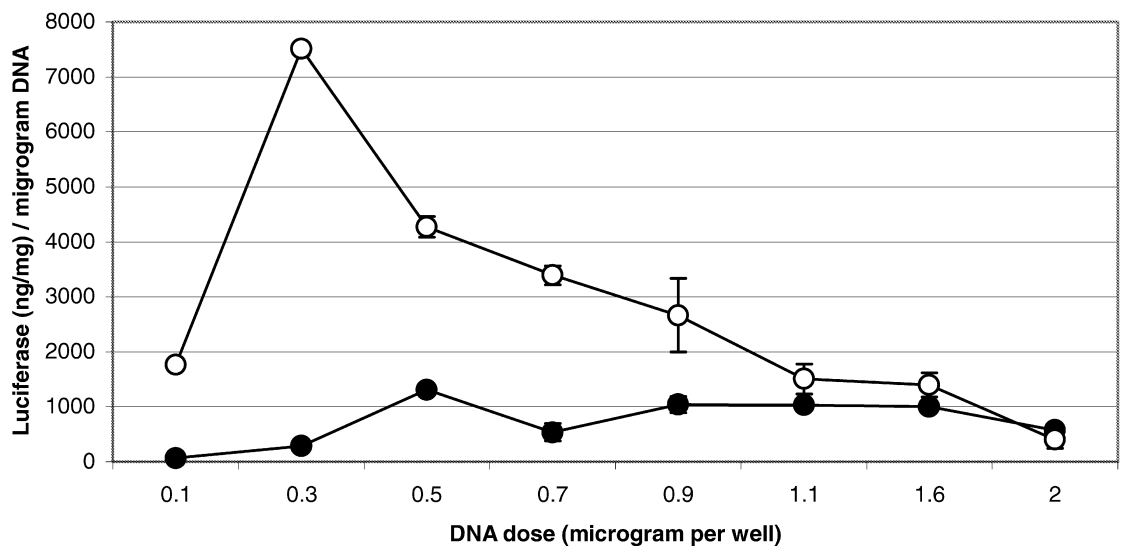

Fig. 5. Comparison of the transfection activity of ExGen ${ }^{\mathrm{TM}}$ 500-based polyplex (empty squares and circles) and LipofectAMINE ${ }^{\mathrm{TM}}$-based lipoplex (filled squares and circles): (A) net transgene expression following 2 and $4 \mathrm{~h}$ exposure of the Cos-7 cells to the transfection systems; (B) relative transgene expression normalized for the DNA dose following $4 \mathrm{~h}$ exposure of the cells to the transfection systems. Transfections were performed using $95 \%$ confluent cells in 24-well plates, which were exposed to the transfection systems in the absence of serum for $2 \mathrm{~h}$ (filled and empty squares) and $4 \mathrm{~h}$ (filled and empty circles). The data are presented as means \pm S.D. $(n=3)$. 
The transfection activities and cytotoxic effects of the four active polyplexes (Superfect ${ }^{\mathrm{TM}}, \mathrm{ExGen}^{\mathrm{TM}}$ 500, P123-g-PEI(2K), PEI (25K)) and four commonly used lipoplexes (Lipofectin ${ }^{\circledR}$, LipofectAMINE ${ }^{\mathrm{TM}}$, CeLLFECTIN ${ }^{\circledR}$ and DMRIE-C) was further compared in another experiment using Cos-7 cells. In this experiments cells were used at $85 \%$ confluency and cells were exposed to transfection complexes for $5 \mathrm{~h}$, the duration suggested by the manufacturer of the lipid Transfection Reagent Sample Pack. The transfections were performed both in the presence and absence of serum for polyplexes, and in the absence of serum for lipoplexes, to comply with the lipoplex manufacturer protocol. Since there was little difference in the luciferase levels for polyplexes transfected in the presence and absence of serum, only the transfections in the absence of the serum are presented. Polyplexes were transfected at their optimal N/P ratios as defined in Table 1 , with a DNA dose of $0.75 \mu \mathrm{g}$ per well in 24-well plates. The lipoplexes were titrated with DNA doses of $0.1,0.4$ and $1.6 \mu \mathrm{g}$ per well as suggested for the optimization of transfection by the manufacturer. As is seen in Table 3, LipofectAMINE ${ }^{\mathrm{TM}}$ was the most efficient of the four lipoplexes tested at the DNA dose of 0.4 and 1. $6 \mu \mathrm{g}$ per well. In fact, at the cell confluency and exposure time used in this experiment LipofectAMINE $^{\mathrm{TM}}$ appeared even more effective than any of the polyplexes examined. The next best performing lipid, DMRIE-C produced less than half as much luciferase as LipofectAMINE ${ }^{\mathrm{TM}}$ at 0.4 and $1.6 \mu \mathrm{g}$ per well. It should be noted that the performance of lipoplexes appeared exaggerated due to the effect of normalization of the data per mg of cell protein. In this experiment the toxicity effects of transfection systems were quite pronounced because the confluency of the cells was relatively low and the exposure time was longer than in the previous experiment. At higher DNA doses (0.4-1. $6 \mu \mathrm{g} /$ well) lipoplexes decreased cellular protein levels to ca. $60-75 \%$ of those in the control wells (exposed to the same amount of the naked DNA). Overall the lipoplexes were obviously more toxic than the polyplexes. As a result, even at the lower doses of DNA used, the lipoplexes exhibited higher toxicity than polyplexes (Table 3 ).

\subsection{Cell toxicity of polyplexes versus the toxicity of free polycation}

To identify the components of the transfection systems that are responsible for the cytotoxic effects of polyplexes, the toxicity of DNA/polycation complexes versus free polycations was examined using an MTT assay with Cos-7 cells. The data are summarized in Fig. 6 for five representative poly-

Table 3

Results of transfection of Cos-7 cells using polyplexes and lipoplexes

\begin{tabular}{|c|c|c|c|}
\hline Transfection system & $\begin{array}{l}\text { DNA dose } \\
(\mu \mathrm{g} / \text { well })^{\mathrm{a}}\end{array}$ & $\begin{array}{l}\text { Luciferase, } \% \text { of } \\
\text { ExGen }^{\text {тм }} 500\end{array}$ & $\begin{array}{l}\text { Cellular protein, } \\
\% \text { of control }\end{array}$ \\
\hline ExGen $^{\mathrm{TM}} 500$ & 0.75 & 100 & 79 \\
\hline Superfect $^{\mathrm{TM}}$ & 0.75 & 134 & 84 \\
\hline PEI (25K) & 0.75 & 39 & 85 \\
\hline P123-g-PEI (2K) & 0.75 & 106 & 82 \\
\hline \multirow[t]{3}{*}{ Lipofectin $^{\circledR}$} & 0.1 & 45 & 86 \\
\hline & 0.4 & 40 & 63 \\
\hline & 1.6 & 26 & 58 \\
\hline \multirow[t]{3}{*}{ LipofectAMINE $^{\mathrm{TM}}$} & 0.1 & 10 & 82 \\
\hline & 0.4 & 176 & 61 \\
\hline & 1.6 & 132 & 67 \\
\hline \multirow[t]{3}{*}{ CeLLFECTIN ${ }^{\circledR}$} & 0.1 & 6 & 79 \\
\hline & 0.4 & 8 & 67 \\
\hline & 1.6 & 3 & 56 \\
\hline \multirow[t]{3}{*}{ DMRIE-C } & 0.1 & 19 & 67 \\
\hline & 0.4 & 72 & 75 \\
\hline & 1.6 & 42 & 66 \\
\hline
\end{tabular}

\footnotetext{
${ }^{\mathrm{a}}$ Transfection was conducted in 24-well plates for $5 \mathrm{~h}$ in the absence of serum, cells were at $85 \%$ confluency.
} 


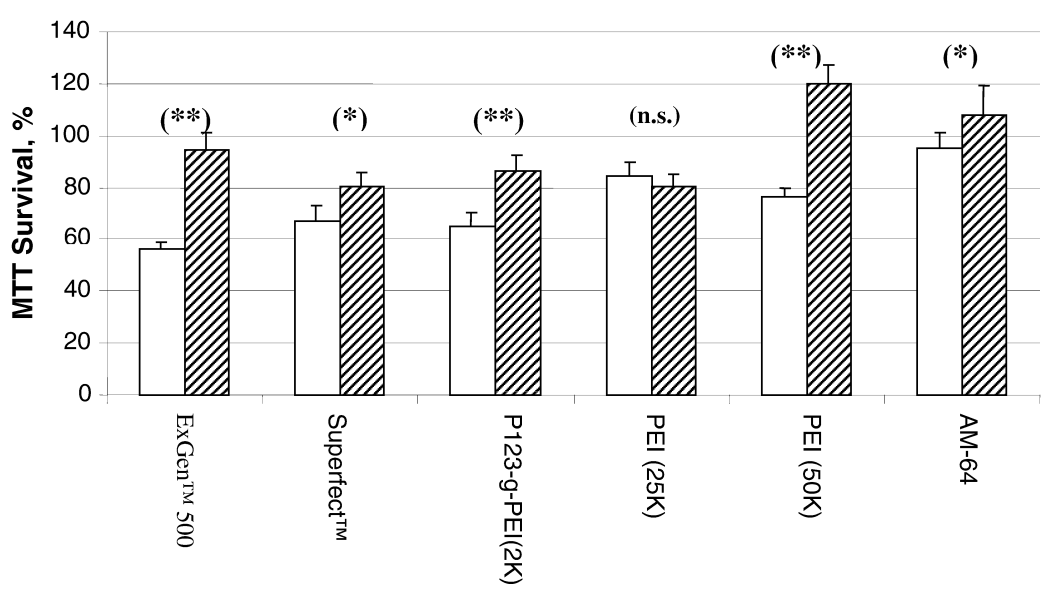

Fig. 6. Evaluation of the toxicity of DNA containing polyplexes at the optimal N/P ratio (white bars) verses the equivalent dose of free polycation (striped bars). Cos-7 cells were grown to $80 \%$ confluency, and then were exposed to the polyplexes at a DNA dose of 0.126 $\mathrm{mg} /$ well $(3 \mu \mathrm{g} / \mathrm{ml})$ in 96-well plates in the presence of serum for $4 \mathrm{~h}$. For experiment involving free polycations, cells were exposed to the same concentrations of polycations as those used with polyplexes for $4 \mathrm{~h}$. Percent of cell survival was determined using a MTT assay. The data are presented as means \pm S.D. $(n=3)$. Statistical significance comparing the polyplexes and corresponding polycations is shown as follows: n.s., non-significant; $* P<0.05 ; * * P<0.005(n=3)$.

plexes. Generally, exposure of the cells to free polycations did not produce significant toxicity, as none of the examined samples exhibited survivals below $80 \%$ of control (cells exposed to the polycation-free media). At the same time, several polyplexes demonstrated significant increase in toxicity compared to the equivalent dose of the free polycations. The increased toxicity of the polyplexes versus free polycations was most pronounced with ExGen ${ }^{\mathrm{TM}}$ 500. In the presence of the ExGen ${ }^{\mathrm{TM}}$ 500-based polyplexes, the percent survival was decreased by ca. $40 \%$ compared to the polycations alone. The next most significant difference was observed with P123g-PEI, in which survival was decreased by $30 \%$. Superfect $^{\mathrm{TM}}$, PEI (25K) and Am-64 did not display a similar increase in toxicity in the polyplex form compared to the free polycations.

\subsection{Particle size measurements}

Polyplex sizes were examined at the optimal transfection ratios using dynamic light scattering. Particle size measurements were obtained by forming complexes in the complete media (containing final concentration of ca. 8\% FBS) as described in Section 2. The transfecting solutions containing polyplexes were found to contain measurable complexes with effective diameters of $100 \mathrm{~nm}$ and more (Table 1). The control samples containing DNA, but prepared in the absence of polycations, also exhibited measurable particles, which were, however, much smaller $(15-18 \mathrm{~nm})$. By measuring particle size in the same media with DNA but without serum we were able to determine that these small particles were a result of the serum component, i.e., most likely had no relationship to the macromolecules of DNA present in the solution. The effective diameters determined for the polyplex systems are presented in Table 1 . Superfect $^{\mathrm{TM}}$ and ExGen ${ }^{\mathrm{TM}} 500$ both produced particles of ca. $120 \mathrm{~nm}$. Polyplexes based on P123-gPEI were only slightly larger (ca. $150 \mathrm{~nm}$ ). All other polyplexes exhibited significant aggregation (ca. $240-420 \mathrm{~nm}$ ). All polyplex systems displayed a very broad range of particle size distribution, with polydispersity indexes more than 0.25 (data not shown). ${ }^{1}$

\subsection{Electrophoresis of complexes}

In order to characterize the process of formation of

\footnotetext{
${ }^{1}$ For monodisperse or nearly monodisperse samples, the polydispersity index is close to $0(0.00-0.02)$; for narrow size distributions, it ranges from 0.02 to 0.10 , and for broader size distributions it exceeds 0.10 .
} 


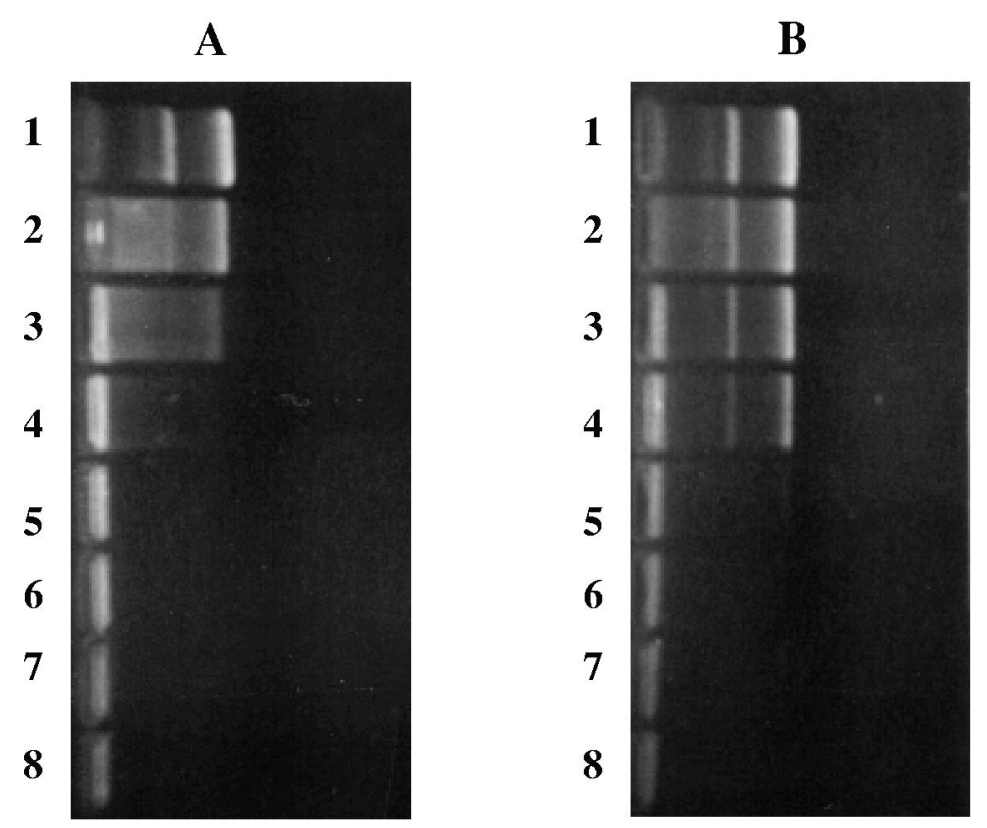

Fig. 7. Agarose gel electrophoresis of pCMV-Luc plasmid and (A) its complexes with P123-g-PEI(2K), or (B) its complexes with PEI(25K), at different N/P ratios: 0 (lane 1), 0.5 (lane 2), 1.0 (lane 3), 1.5 (lane 4), 2.0 (lane 5), 2.5 (lane 6), 3.0 (lane 7), 4.0 (lane 8).

polyplexes, plasmid DNA and polycations were mixed in $\mathrm{ddH}_{2} \mathrm{O}$ and subjected to agarose gel electrophoresis. Fig. 7A represents a typical result observed for the copolymer P123-g-PEI(2K) and the dendrimer Am-64. Based upon these data, all DNA present in the system appeared to associate with the polycation over the entire range of $\mathrm{N} / \mathrm{P}$ ratios examined. The polyplexes remained soluble and migrated through the gel. However, the movement of the plasmid in the gel was retarded suggesting gradual neutralization of the DNA charge. At N/P ratio ca. 2.0, the complex of $\mathrm{P} 123-\mathrm{g}-\mathrm{PEI}(2 \mathrm{~K})$ and DNA was neutral since it did not migrate in the electric field. Am-64 completely neutralized DNA at $\mathrm{N} / \mathrm{P}$ ratio 4.

A distinct type of behavior was observed for PEI (25K), PEI (50K), ExGen ${ }^{\mathrm{TM}}$ 500, Superfect ${ }^{\mathrm{TM}}$ and $\mathrm{PEVP}_{362}$. Fig. 7B represents a typical result obtained for those polycations. Formation of the complexes was evident by the decreased intensity of the free DNA following addition of the polycation. However, in contrast to the previous case, the DNA incorporated into the complex did not migrate and was retained in the well. The $\mathrm{N} / \mathrm{P}$ ratios corresponding to complete retention of the DNA are also presented in
Table 1 for each polycation. In most cases these ratios were more than $\mathrm{N} / \mathrm{P}=1$, meaning that the excess of nitrogen atoms per phosphate is required for complete neutralization of the DNA charge. This is explained by incomplete protonation of the nitrogen atoms of the respective polycations under the conditions studied. The only exception is $\mathrm{PEVP}_{362}$, in which all nitrogen atoms are charged (quaternized). For this polycation complete neutralization of the DNA charge occurs at $\mathrm{N} / \mathrm{P}=1$.

The neutralization points for all polyplexes studied in this work are presented in Table 1 to compare them with the optimal transfection $\mathrm{N} / \mathrm{P}$ ratios discussed earlier. In all cases with the exception of Am-64 it appeared that the excess of the polycation compared to the neutralization points defined above was required for optimal transfection.

\section{Discussion}

This work reports the comparison of a diverse group of transfection systems in respect to their effectiveness and toxicity in a variety of cell types in vitro. The polycations were chosen to represent all 
major molecular architectures of polycations that are currently being used for gene delivery: linear, randomly branched, dendrimeric, block- or graft copolymer. The polycations used included PEI and polyamidoimine dendrimer that are well-established transfection agents $[17,18]$. This work also included a relatively poorly studied poly(propyleneimine) dendrimer, Astramol ${ }^{\mathrm{TM}}$, which based upon our data has shown very low activity. A recently developed Pluronic-based graft-block copolymer, P123-gPEI(2K), represented a novel amphiphilic polycation transfection family, which is relatively unexplored [14]. By comparing poly[ $N$-ethyl-4-vinyl pyridinium bromide], $\mathrm{PEVP}_{362}$ [19], with the more recently developed and more active polycations, one can illustrate the progress that has been achieved during the last decade in the development of polyplexes for non-viral gene delivery. Another early used polycation, polylysine [20], was not included in this study because a comprehensive work is available comparing this polycation with polyethyleneimine and polyamidoamine dendrimer, which suggests that polylysine is practically inactive when it is not conjugated with a ligand capable of receptor-mediated endocytosis into a cell [6].

Using a panel of 10 cell lines that drastically differ in 'transfectability', this study allows for the ranking of polycation transfection systems. It suggests that ExGen $^{\text {TM }}$ 500, Superfect ${ }^{\text {TM }}$, PEI (25K) and P123-gPEI $(2 \mathrm{~K})$ comprise a group of relatively more active agents. In contrast, PEI (50K), Am-64 and PEVP 362 are significantly less active. By comparing various polyplexes with each other, the results of this work demonstrate that the differences in performance of these transfection systems cannot be directly related just to the structural differences of the polycations used for their preparation. Indeed, the group of the more active polycations includes distinctly different molecules representing linear, randomly branched, dendrimer and graft-block copolymer architectures. Likewise, the worst performing polycations include both linear and dendrimer molecules. The absence of a simple correlation between transfection activity and structure of the polycation is further illustrated using the example of the three PEI samples studied in this work. PEI (25K), a randomly branched molecule, contains approximately equivalent portions of primary, secondary and tertiary nitrogen atoms [14].
PEI (50K) and ExGen ${ }^{\text {TM }} 500$ (PEI (22K)) are both linear molecules, containing major portion of secondary nitrogen atoms. However, the transfection levels observed with PEI (50K) are significantly lower than those observed with PEI (25K), while ExGen $^{\text {TM }} 500$ clearly outperforms the two other polycations. The differences in the transfection activities of the polycations cannot be clearly correlated with the toxicity of the polyplexes. Furthermore, the more active ExGen ${ }^{\text {TM }}$ 500-based polyplexes also appeared to be the most toxic, based on the majority of our evaluation experiments. At the same time the relatively less active PEI $(25 \mathrm{~K})$ and PEI $(50 \mathrm{~K})$ appear to be less toxic than ExGen ${ }^{\mathrm{TM}} 500$.

Previous work suggested that the weak base polycations promote transfection by preventing degradation of DNA by lysosomal enzymes and by enhancing the release of DNA from the endocytic vesicles $[17,18]$. This was related to the buffering capacity of the weak base polycations and became very well known as the 'proton sponge hypothesis' [18]. All of the relatively active polycations $\left(\right.$ ExGen $^{\text {TM }}$ 500, Superfect ${ }^{\mathrm{TM}}$, PEI (25K), P123-g$\operatorname{PEI}(2 \mathrm{~K})$ ) are weak bases having ionizable primary and/or secondary nitrogen atoms that can protonate. However, the group of the worst performers along with a strong base, $\mathrm{PEVP}_{362}$, which does not protonate, also contains PEI (50K) and Am-64, both potentially capable of the protonation. This clearly suggests that the ability of the polycations to bind protons resulting in the buffering properties is at least not a sufficient factor to ensure a high transgene expression.

The reservations about the proton sponge hypothesis, at least in its most well-known form [21], has been reinforced by the recent study by von Harpe et al [22]. By comparing various polyethyleneimine samples with a broad range of molecular weights this study has demonstrated that the area of high buffer capacity of polyethyleneimines lies above the physiological range ( $\mathrm{pH} 8-9.5)$. In the range between $\mathrm{pH}$ 4.5 and 7.4 characteristic for the lysosomal compartment, the buffer capacity is negligibly low and the differences in the buffer capacity between polyethyleneimines are marginal. Therefore, polyethyleneimines are unlikely to be effective 'proton sponges' in the endosomal and lysosomal compartments. Furthermore, the buffer capacity effects can- 
not explain the dramatic difference in the transfection activity exhibited by various polyethyleneimine samples reported in this and some other work [23].

It has been suggested previously that the size of the polyplex species is a critical parameter that affects transgene expression [4,6,24,25]. Generally, it is believed that the small size of the particles and the absence of aggregation favor the transfection because it facilitates entry of the polyplexes into cells via endocytosis [3]. However, when analyzing the sizetransfection activity relationship in polyplex systems one must take into account the two following factors. First, the particle size of polyplexes is very sensitive to the nature of simple salts present in the buffer $[14,25]$. Second, measurements of the sizes of polyplexes conducted in the absence of serum could lead to drastically different results compared to those performed in serum-containing media $[14,25]$. Therefore, we have obtained size measurements by forming polyplexes exactly as would be done in our standard transfection protocol, which contains cell culture media supplemented with FBS. The results of these studies suggest that three of the four active polyplexes form relatively small particles. One of these polyplexes, PEI (25K), as well as all three low performing systems, form much larger aggregates. In this respect the rather significant polydispersity of the samples, i.e., a broad range of particle size distribution within the sample observed for all polyplexes, is worth consideration. For example, coexistence of larger aggregates as well as a fraction of small $(40 \mathrm{~nm})$ particles was previously reported for PEI (25K)-based polyplexes [6]. Due to a wellknown property of a light scattering technique, the presence of even a relatively small portion of large aggregates in the dispersion can completely mask the presence of small particles. Although the majority of work suggests that small polyplexes are necessary for high transfection (for review see Ref. [3]) we believe that the question about the relationship between size and transfection activity is far from resolved. Some authors suggested that large polyplex aggregates are more active in the transfection [25], but this conclusion of course might be affected by the sample polydispersity, which was not reported. The measurements of the effective diameter alone are not always sufficient for prediction of the polyplex activity in in vitro assays. Nevertheless, the absence of aggregation observed with $\operatorname{ExGen}^{\mathrm{TM}} 500$, Superfect $^{\mathrm{TM}}$, and P123-g-PEI (2K) is essential for application of these systems in gene delivery [14].

The ratio of the concentration of a polycation and DNA in the polyplex has been long recognized as a critical parameter for optimization of transfection $[18,24]$. Based upon the electrophoresis studies the DNA is completely incorporated in the polyplexes at the optimal transfection conditions. Furthermore, in most cases an excess of the polycation is required to achieve maximal transgene expressions (Table 1). Previously it was suggested that excess of polycation results in the formation of polyplexes displaying positive charge at their surface, which facilitates interaction with negatively charged moieties at the cell surface [26]. The only exception is dendrimer Am-64, for which the optimal transfection ratio was equivalent to the ratio at which all DNA is incorporated into the complex $(\mathrm{N} / \mathrm{P}=4)$. Recent study allows us to suggest that this may be related to the rigidity of Am-64 dendrimer, which upon interaction with the DNA exposes a portion of its primary nitrogen groups at the surface of the complex [13]. Therefore, Am-64-based polyplexes can display positive charge at their surface even at the point of the net charge neutralization $(\mathrm{N} / \mathrm{P}=4)$.

One concern that has been raised in literature is that polycation molecules can induce cytotoxic response due to their high positive charge [7,24]. Furthermore is has been hypothesized that "free polycation may harm cells, but when bound to DNA its detrimental effects are greatly lessened" [7]. Our data directly contradict such a hypothesis. Based on the present study the observed toxicity of polyplexes is the same or higher than that of the equivalent doses of free polycations. Furthermore, it appears that some of the more active polyplexes, such as those based on ExGen ${ }^{\mathrm{TM}}$ 500, Superfect ${ }^{\mathrm{TM}}$, and P123g-PEI, are also the most toxic compared to other polyplexes. It is possible that at least some portion of toxicity is attributed to the DNA incorporated into the polyplex. Upon delivery of higher dose of intact DNA into the cell a cellular stress response may be induced, which may lead to apoptosis [27]. Furthermore, initiation of the stress response upon transfection results in enhancement of expression of the reporter construct under the control of the CMV promoter [27]. This means that high transgene 
expression may be to a certain extent intrinsically related to the cytotoxic effects induced by the transfection construct including CMV promoter used in our work. This hypothesis, however, remains unproven until more data is obtained in future studies, for example, using polyplexes with plasmids under the control of different promoters.

This study suggests that the in vitro efficacy of polyplexes may be a complex function of the cell confluency and exposure time. Generally one may expect that increasing the time of the exposure of the cells to polyplex can result in enhancement of the transfection. This appears to be the case for the polyplexes for which a relatively low toxicity is observed (such as Superfect ${ }^{\mathrm{TM}}$ system shown in Fig. 4). However, if there is significant cytotoxicity from the polyplex it might impede the benefit of increasing the times exposure. For example, when the cells were transfected with the ExGen ${ }^{\text {TM }}$ 500-based polyplexes there was no or little (compared to Superfect ${ }^{\mathrm{TM}}$ ) boost in the luciferase expression upon increase in the exposure time from 2 to $4 \mathrm{~h}$ (Fig. 4). ExGen $^{\text {TM }}$ 500-based polyplexes were more cytotoxic than other active polyplexes and resulted in the reduction of cellular protein levels. The cytotoxic effects were strongly reduced when the cell confluency was increased. This might be one reason why the transgene expression when using ExGen ${ }^{\mathrm{TM}} 500$ was increasing when the confluency of the cells increased.

Cytotoxic effects appear to be particularly important in the comparison of polyplexes and lipoplexes conducted in the present study. Given the variability between different cell types as well as interexperimental variability in transfection experiments our studies cannot definitively conclude that polyplexes outperform lipoplexes in the levels of transgene expression. However, it does appear that lipoplexes are more toxic than polyplexes. Furthermore it appears that the profound toxicity of the lipoplexes is a limiting factor to their maximal dose that can be used in cell transfection. While dose limitations are also characteristic of the polyplexes, the tolerable doses of DNA in this case are higher than in the case of lipoplexes. Finally, relatively high levels of the transgene expression and low levels of toxicity are observed for polyplexes independently of presence or absence of serum. This might provide for greater flexibility in the transfection compared to the selected lipoplex systems that according to the manufacturer's protocol should be used in the absence of serum.

Like lipoplexes the polyplexes also reveal tremendous dependence on the cell line used. A recent study by the group of Wagner has demonstrated that both lipoplexes and polyplexes are inefficient in nondividing cells [28]. However, in this work we do not see differences in the cell growth rates that can account for the staggering differences in transgene expression. Therefore the reasons for the cell type dependency observed in this work might be quite complex. It could include differences in endocytosis and intracellular transport of polyplexes between various cell lines resulting in different amounts of DNA reaching its final destination in the cell. On the other hand the promoter activity as well as activity of the protein synthesis machinery might be different and limiting the transgene expression with both lipoplexes and polyplexes in different cell lines.

Overall the results of the present work clearly demonstrate that polyplex-based systems have, at least, 'caught up with' the lipoplex technology. Still, at least based upon the present in vitro evaluation, some of the limitations that are inherent for the lipoplexes also remain the obstacles that hinder the polyplex transfections. This refers to a significant cell type dependence of the transgene expression observed in this study for some of the most effective polyplex systems.

\section{Acknowledgements}

The authors wish to thank the National Science Foundation (BES-9907281) and the Nebraska Research Initiative Gene Therapy program for supporting this research. We would like to thank Supratek Pharma Inc. for providing the sample of P123-g$\operatorname{PEI}(2 \mathrm{~K})$, that was synthesized by Dr. Sergey Vinogradov. M-H-W Laboratories (Phoenix, AZ) did elemental analysis. We would like to thank BASF for the gift of Pluronic P123 and Dr. Albert Descoteaux (Armand Frappier Institute, Montreal, PQ, Canada) for providing the pCMV-Luc plasmid. We would also like to acknowledge Dr. Valery Alakhov and Dr. 
Pierre Lemieux for their valuable discussion of this work.

\section{References}

[1] P. Felgner, Y. Barenholz, J.P. Behr, S.H. Cheng, P. Cullis, L. Huang, F.J. Jessee, L. Seymour, F. Szoka, A.R. Thierry, E. Wagner, G. Wu, Nomenclature for synthetic gene delivery systems, Hum. Gene Ther. 8 (1997) 511-512.

[2] R. Christiano, Viral and non-viral vectors for cancer gene therapy, Anticancer Res. 18 (1998) 3241-3246.

[3] A. Kabanov, Taking polycation gene delivery systems from in vitro to in vivo, Pharm. Sci. Tech. Today 2 (9) (1999) 1461-5347.

[4] S. De Smedt, J. Demeester, W. Hennink, Cationic polymer based gene delivery systems, Pharm. Res. 5 (2000) 14251433.

[5] F. Ledley, Nonviral gene therapy: the promise of genes as pharmaceutical products, Hum. Gene Ther. 6 (9) (1995) 1129-1144.

[6] M. Tang, F. Szoka, The influence of polymer structure on the interactions of cationic polymers with DNA and morphology of the resulting complexes, Gene Ther. 4 (1997) 823-832.

[7] W. Godbey, K.K. Wu, A.G. Mikos, Poly(ethylenimine) and its role in gene delivery, J Control. Release 60 (1999) $149-160$.

[8] O. Boussif, M. Zanta, J. Behr, Optimized galenics improve in vitro gene transfer with cationic molecules up to 1000fold, Gene Ther. 3 (12) (1996) 1074-1080.

[9] D. Dunlap, A. Maggi, M.R. Soria, L. Monaco, Nanoscopic structure of DNA condensed for gene delivery, Nucleic Acids Res. 25 (15) (1997) 3095-4101.

[10] A.V. Kabanov, I.V. Astafieva, I.V. Maksimova, E.M. Lukanidin, G.P. Georgiev, V.A. Kabanov, Efficient transformation of mammalian cells using DNA interpolyelectrolyte complexes with carbon chain polycations, Bioconjug. Chem. 4 (1993) 448-454.

[11] M.X. Tang, C.T. Redemann, F.C.J. Szoka, In vitro gene delivery by degraded polyamidoamine dendrimers, Bioconjug. Chem. 7 (1996) 703-714.

[12] E. De Brabander, J. Brackman, M. Mure-Mak, H. deMan, M. Hogeweg, J. Keulen, R. Scherrenberg, B. Coussens, Y. mergerink, S. van der Wal, Polypropyleneimine dendrimers: improved synthesis and characterization, in: Macromol. Symp., 1996.

[13] V. Kabanov, A.B. Zezin, V.B. Rogacheva, Z.G. Gulyaeva, M.F. Zansochova, J.G.H. Joosten, J. Brackman, Polyelectrolyte behavior of Astramol poly(propyleneimine) dendrimers, Macromolecules 31 (15) (1998) 5142-5144.

[14] H.-K. Nguyen, P. Lemieux, S.V. Vinogradov, C.L. Gebhart, N. Guerin, G. Paradis, T.K. Bronich, V.Y. Alakhov, A.V. Kabanov et al., Evaluation of polyether-polyethyleneimine graft copolymers as gene transfer agents, Gene Ther. 7 (2) (2000) 126-138.
[15] S. Starodubtzev, Y. Kirsh, V. Kabanov, Solvation effects and reactivity of free pyridine residues in macromolecules of poly-4-vinylpyridine, Eur. Polym. J. 10 (1987) 739-745.

[16] W.W. Daniel, in: Biostatistics, 6th Edition, Wiley, New York, 1995.

[17] J. Haensler, F.J. Szoka, Polyamidoamine cascade polymers mediate efficient transfection of cells in culture, Bioconjug. Chem. 4 (5) (1993) 372-379.

[18] O. Boussif, F. Lezoualc'h, M.A. Zanta, M.D. Mergny, D. Sherman, B. Demeneix, J.P. Behr, A versatile vector for gene and oligonucleotide transfer into cells in culture and in vivo — polyethyleneimine, Proc. Natl. Acad. Sci. USA 92 (1995) 7297-7301

[19] A. Kabanov, V.I. Kiselev, M.L. Chikindas, I.V. Astafieva, A.I. Glukhov, S.A. Gordeev, V.A. Izumrudov, A.B. Zezin, A.V. Levashov, E.S. Severin, V.A. Kabanov, Increasing of transforming activity of plasmid DNA by incorporating it into an interpolyelectrolyte complex with a carbon chain polycation, Dokl. Akad. Nauk. SSSR (in Russian) 306 (1989) 226-229.

[20] G. Wu, C. Wu, Receptor-mediated in vitro gene transformation by a soluble DNA carrier system, J. Biol. Chem. 262 (1987) 4429-4432.

[21] J. Behr, The proton sponge: a trick to enter cells the viruses did not exploit, Chimia 51 (1997) 34-36.

[22] A. von Harpe, H. Petersen, Y. Li, T. Kissel, Characterization of commercially available and synthesized polyethylenimines for gene delivery, J. Control. Release 69 (2) (2000) 309322.

[23] W. Godbey, K. Wu, A. Mikos, Size matters: molecular weight affects the efficiency of poly(ethylenimine) as a gene delivery vehicle, J. Biomed. Mater. Res. 45 (3) (1999) $268-275$.

[24] A. Kabanov, V. Kabanov, DNA complexes with polycations for the delivery of genetic material into cells, Bioconjug. Chem. 6 (1995) 7-20.

[25] M. Ogris, P. Steinlein, M. Kursa, K. Mechtler, R. Kircheis, E. Wagner, The size of DNA/transferrin-PEI complexes is an important factor for gene expression in cultured cells, Gene Ther. 5 (1998) 1425-1433.

[26] A. Kabanov, F.J. Szoka, L. Seymour, Interpolyelectrolyte complexes for gene delivery: polymer aspects of transfection activity, in: A. Kabanov, P. Felgner, L. Seymour (Eds.), Self-assembling Complexes for Gene Delivery. From Laboratory to Clinical Trial, Wiley, Chichester, UK, 1998, pp. 197-218.

[27] J. Andrews, G. Newbound, M. Lairmore, Transcriptional modulation of viral reporter gene constructs following induction of the cellular stress response, Nucleic Acids Res. 25 (5) (1997) 1082-1084.

[28] S. Brunner, T. Sauer, S. Carotta, M. Cotten, M. Saltik, E. Wagner, Cell cycle dependence of gene transfer by lipoplex, polyplex and recombinant adenovirus, Gene Ther. 7 (5) (2000) 401-407. 